[Agr. Biol. Chem., Vol. 34, No. 11, p. 1625 1632, 1970]

\title{
Studies on the Formation of Uricase by Streptomyces
}

\author{
Part II. The Induced Formation of Uricase \\ by the Resting Cells ${ }^{\dagger}$
}

\author{
By Yasuto Watanabe and Juichiro Fukumoto* \\ Osaka Municipal Institute of Technology, *Faculty of Science, \\ Osaka City University
}

Received March 23, 1970

\begin{abstract}
A strain of Streptomyces sp. produced little of uricase in the cells when they were grown in a medium consisted of peptone, glucose and inorganic salts, even in the presence of urate. The cells, however, formed a large amount of the enzyme, when they were incubated with urate in $\mathrm{K}$-phosphate buffer. The amount of uricase thus formed was maximum by the cells which were harvested at the middle logarithmic phase of the preliminary growth. The induced formation of uricase required $\mathrm{K}$ ions in addition to $\mathrm{Mg}$ ions and was accelerated by glucose and some other carbon sources. The enzyme formation was inhibited completely by chloramphenicol at a low concentration. An equimolar allantoin to urate decomposed by the cells was accumulated in the incubation mixture. More than 3.0 units of uricase per $\mathrm{g}$ of wet cells were produced under the best conditions known from the present experiments. The derepression of uricase formation in the resting cells incubated in the phosphate buffer was discussed.
\end{abstract}

Uricase (1.7.3.3, urate: oxygen oxidoreductase) of microorganisms has usually been found in the cells which were grown in media containing urate and regarded as an inducible enzyme. However, the studies on the induced formation of uricase by microorganisms have been very limited. ${ }^{1-31}$

A strain of Streptomyces sp. has been found to form a large amount of uricase in the cells which were grown in a medium consisted of peptone, meat extracts, glucose, inorganic salts and urate." The enzyme has been purified

$\dagger$ A part of this report was presented at the meeting of the Kansai Division of the Agricultural Chemical Society of Japan held in Osaka in December, 1967.

1) A. H. Roush and A.J. Domnas, Science, 124, 125 (1956).

2) M. F. Quetsch and W. F. Danforth, $J$. Cellular Comp. Physiol., 64, 115 (1964).

3) C. Scazzocchio and A. J. Darlington, Biochim. Biophys. Acta, 166, 557 (1968).

4) J. Fukumoto, Y. Watanabe and M. Yano, Nippon Nogeikagaku Kaishi, 41, 540 (1967). and found to resemble those from other origins in the enzymatic properties. ${ }^{6 /}$ The removal of meat extracts from the medium resulted in a significant diminution in the amount of uricase produced by the cultured cells, and the addition of hypoxanthine or xanthine to the medium restored the enzyme formation. It thus is suggested that the formation of uricase by this organism would be repressed in the growing cells and that hypoxanthine and xantine might play a role in the derepression. ${ }^{6 !}$

It was found, however, that the cells which had been grown previously in a medium consisted of peptone, glucose and inorganic salts, and no urate nor purines, were able to form a large amount of uricase in a relatively

5) Y. Watanabe, M. Yano and J. Fukumoto, Nippon Nogeikagaku Kaishi 42, 621 (1968).

6) Y. Watanabe, M. Yano and J. Fukumoto, Agr. Biol. Chem., 33, 1282 (1969). 
short time, if the cells were incubated with urate in K-phosphate buffer. The amount of uricase thus produced was larger than that produced by the cultured cells. The present paper is concerned with the induced formation of uricase by the resting cells of Streptomyces sp. incubated with urate in the phosphate buffer.

\section{MATERIALS AND METHODS}

The microorganism used in the present study was a strain of Streptomyces sp. which was isolated and stocked as reported previously,, 6, The media used for the culture of the organism were the peptone medium containing peptone $2.0 \%$, glucose $3.0 \%$, $\mathrm{K}_{2} \mathrm{HPO}_{4} 0.1 \%, \mathrm{MgSO}_{4} \cdot 7 \mathrm{H}_{2} \mathrm{O} 0.05 \%$ and $\mathrm{NaCl} 0.05 \%$, $\mathrm{pH} 7.0$, and the urate medium containing uric acid 0.19 in the peptone medium, $\mathrm{pH}$ 7.0. The cultivation and the harvest of the cells were carried out as described previously. ${ }^{6}$

Standard incubation for uricase formation was described below. The washed cells were incubated, unless otherwise stated, in the mixture containing the cells $0.5 \mathrm{~g}$ in wet weight, $50 \mathrm{mM} \mathrm{K}$-phosphate buffer $(\mathrm{pH} 7.0), 10 \mathrm{mM} \mathrm{MgCl} 2,20 \mathrm{mM}$ glucose and $3.0 \mathrm{~mm}$ urate. Twenty milliliters of the mixture were taken in the L-shaped flask and shaken at $30^{\circ} \mathrm{C}$ for indicated term. The sonic extraction, the assay of uricase of the cells and the determination of urate in the mixture were described in the previous paper.61

Allantoin was determined by a Hitachi model KLA3B Amino Acid Analyzer. An aliquot of the filtrate was applied on the $50 \mathrm{~cm}$-column at $\mathrm{pH} 2.2$ and eluted with the citrate buffer $(\mathrm{pH} 3.25)$. The flow rate of the buffer was $15 \mathrm{ml}$ per $\mathrm{hr}$, of the ninhydrin reagent 7.5 $\mathrm{ml}$ per $\mathrm{hr}$ and the chart speed 3 inches per hr. The peak of allantoin appeared at $130 \mathrm{~min}$ in the chromatogram.

Uric acid was purchased from Wako Pure Chemical Industries Co. and chloramphenicol was a product of Sankyo Co. Other reagents used were the highest grade commercially available.

\section{RESULTS}

The growth and uricase activity of the cells grown in the peptone and urate media are shown in Fig. 1. Only slight activities of the

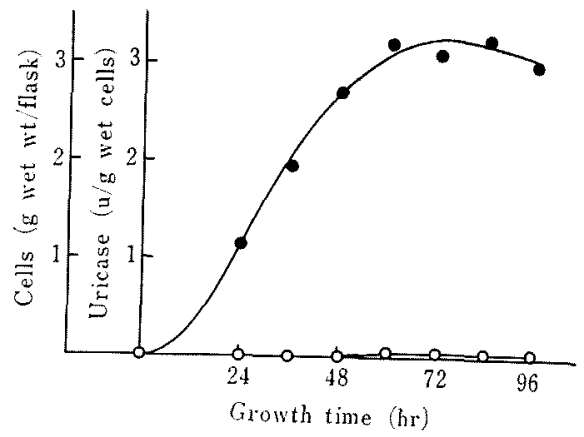

(a)

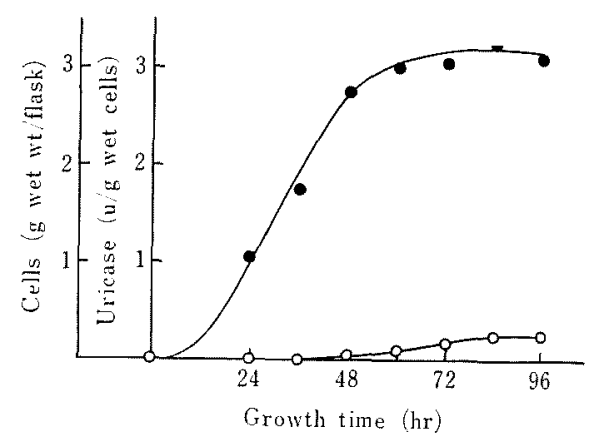

(b)

FIG. 1. Growth and Uricase Activity of the Cells Cultured in the Peptone and Urate Media.

Sixty milliliters of the peptone (a) and urate (b) media were inoculated with spores and kept at $27^{\circ} \mathrm{C}$ with shaking. Cells were harvested by filtering with suction and washed 3 times with water. Uricase was extracted by sonic oscillation and assayed by the spectrophotometric method as previously reported.6; The enzyme activities were so plotted that comparison could be made to the other data reported in the present paper.

$\mathrm{O}-\mathrm{O}$ Uricase and - cells.

enzyme were detected in the cells grown in these media, even in the presence of urate, after the late logarithmic phase of growth. That the low activities in the cells were not due to the presence of substances which inhibit the uricase reaction was confirmed by adding the sonic extracts of the cells to the uricase preparation.

It was found, however, that the uricase activity in the cells increased in a remarkable 
rate when the cells were incubated in $\mathrm{K}$ phosphate buffer with urate. The cells which had been growing in the media were taken at various growth times, washed with water, suspended in the phosphate buffer containing $\mathrm{Mg}$ ions and glucose and incubated with urate. The degradation of urate in the incubation mixture is shown in Fig. 2. Although the degradation followed parabolic curves, urate disappeared most rapidly from the mixture incubated with the cells grown for $36 \mathrm{hr}$. As shown in Fig. 3, the ability of uricase forma-

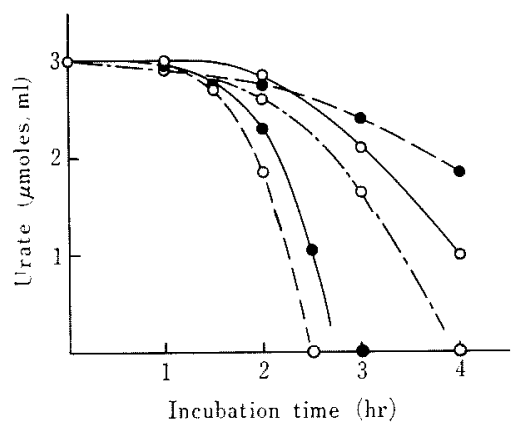

(a)

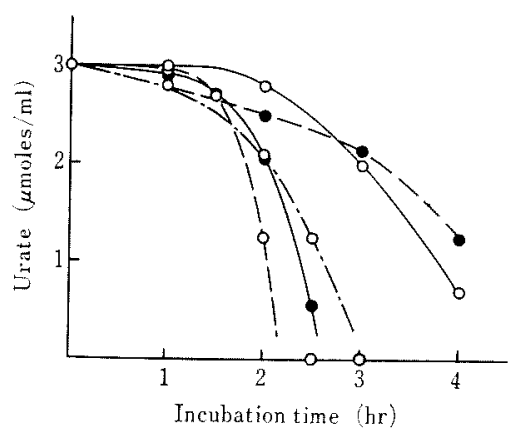

(b)

FIG. 2. Decomposition of Urate by the Cells Previously Grown in the Peptone (a) or Urate (b) Medium.

Washed cells previously grown in the peptone or urate medium for various hours were incubated with urate in K-phosphate buffer (pH 7.0) containing $\mathrm{Mg}$ ions and glucose at $30^{\circ} \mathrm{C}$ with shaking. Urate in the filtrates was determined spectrophotometrically.

O-O $24 \mathrm{hr}-$, O---O $36 \mathrm{hr}$, - $48 \mathrm{hr}-, 0--\mathrm{O}$ $72 \mathrm{hr}$ - and $96 \mathrm{hr}-\mathrm{grown}$ cells.

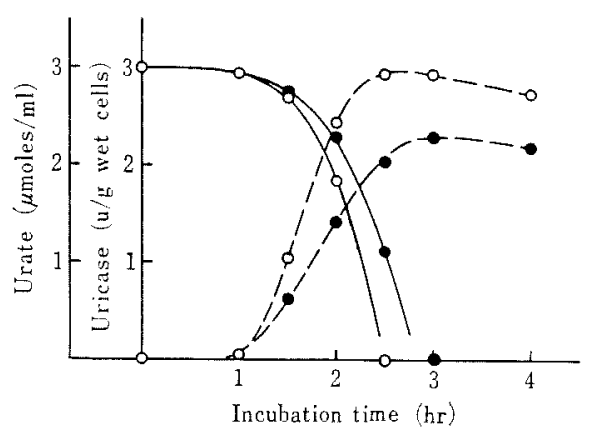

FIG. 3. Uricase Formation and Urate Decomposition by the Cells Previously Grown in the Peptone Medium for 36 and $48 \mathrm{hr}$.

Urate: $0-0,36 \mathrm{hr}-$ and $-\mathbf{0}, 48 \mathrm{hr}$-grown cells. Uricase: $\mathrm{O}^{-\cdots-\mathrm{O}}, 36 \mathrm{hr}-$ and --- $48 \mathrm{hr}-\mathrm{grown}$ cells.



FIG. 4. Effect of $\mathrm{pH}$ on the Urate Decomposition. $\mathrm{O}-\mathrm{O} \mathrm{pH} 5.83, \mathrm{O}-\mathrm{O} \mathrm{pH} 7.00,0-\mathrm{O} \mathrm{pH} 8.60$.

tion was also stronger in the cells grown for $36 \mathrm{hr}$ than in those grown for $48 \mathrm{hr}$. No significant difference was noted in the urate decomposition by the cells which had previously grown in the presence or absence of urate. In further experiments, therefore, the cells used were cultured in the peptone medium for $36 \mathrm{hr}$.

The effect of $\mathrm{pH}$ of the incubation mixture on the degradation of urate is shown in Fig. 4 , and no significant difference was observed in the $\mathrm{pH}$ range of $6.0 \sim 8.5$.

Figure 5 shows the effect of concentration of K-phosphate buffer. Urate in the incubation mixture decreased most quickly at the 




FIG. 5. Effect of Concentration of K-Phosphate Buffer on the Urate Decomposition.


Frg. 6. Effect of Concentration of Phosphate Ions on the Urate Decomposition.

Instead of K-phosphate buffer, $100 \mathrm{~mm}$ Tris buffer (pH 7.0) and $5.0 \mathrm{mM} \mathrm{KCl}$ were used. Phosphate ions were added as Na-phosphate buffer ( $\mathrm{pH} 7.0$ ). The standard incubation was run as described in Methods. O-O Standard incubation, O---O control (without Na-phosphate buffer) and - with $\mathrm{Na}$-phosphate buffer $(0.5 \sim 50 \mathrm{mM})$.

concentrations of $20 \sim 50 \mathrm{~mm}$. The concentration of phosphate ions necessary for the urate decomposition was $0.1 \mathrm{~mm}$ as shown in Fig. 6 .

In Fig. 7 is shown the decrease in urate when the incubations were performed in $\mathrm{Na}$ or K-phosphate buffer. The results indicated the requirement of $\mathrm{K}$ ions for the induced formation of uricase under the present conditions. The requisite concentration of $\mathrm{K}$ ions to the urate degradation was $5.0 \mathrm{mM}$ as seen from Fig. 8.

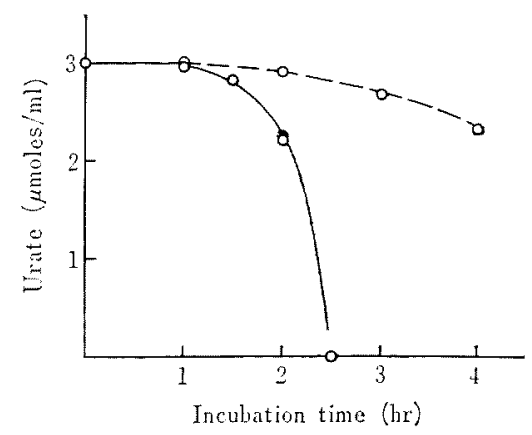

FIG. 7. Effect of $\mathrm{K}$ Ions on the Urate Decomposition.

KNa-phosphate buffer was prepared by mixing an equal volume of $\mathrm{K}$ - and $\mathrm{Na}$-phosphate buffers. $\mathrm{O}-\mathrm{O} \mathrm{K}-(50 \mathrm{mM}), \mathrm{O}-\mathrm{O} \mathrm{Na}-(50 \mathrm{mM})$ and KNa-phosphate $(50 \mathrm{~mm})$ buffers.



FIG. 8. Effect of Concentration of $\mathrm{K}$ Ions on the Urate Decomposition.

Incubation mixtures were prepared with Naphosphate buffer and $\mathrm{K}$ ions were added as $\mathrm{KCl}$. $\bigcirc-O$ Standard incubation, $\bigcirc--O$ control (without $\mathrm{K}$ ions), $0.5 \mathrm{~mm} \mathrm{~K}$ ions, $\mathrm{O}--\mathrm{O} 1.0 \mathrm{mM} \mathrm{K}$ ions and $5 \sim 50 \mathrm{mM} \mathrm{K}$ ions.

The effect of metal ions on the decomposition of urate is shown in Fig. 9. Of the metal ions tested, $\mathrm{Mg}$ ions stimulated the decomposition, while $\mathrm{Ni}$, Co and $\mathrm{Fe}$ ions inhibited. The effect of $\mathrm{Mg}$ ions was optimum at the concentrations of $10 \sim 20 \mathrm{mM}$ as shown in Fig. 10.

In Fig. 11 is shown the effect of sugars and some other carbon sources on the urate degradation. The addition of glucose, fructose or mannose to the incubation mixture brought 




FIG. 9. Effect of Metal Ions on the Urate Decomposition.

$\mathrm{MgSO}_{4}, \mathrm{CaCl}_{2}, \mathrm{MnSO}_{4}, \mathrm{ZnSO}_{4}, \mathrm{FeSO}_{4}, \mathrm{NiSO}_{4}$ or $\mathrm{CaSO}_{4}$ was added to the standard incubation mixture in the concentration of $10 \mathrm{~mm}$.

$\mathrm{O}-\mathrm{O}$ Control (without addition), $\mathrm{O}---\mathrm{OMg}$,

$\mathrm{Ca}, \mathrm{O}^{--\mathrm{O}} \mathrm{Mn}$, $\mathrm{Zn}$,

$\mathrm{Ni}$, Co ions.

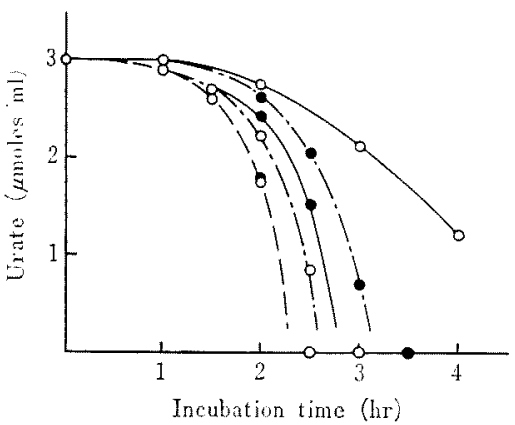

FIG. 10. Effect of Concentration of Mg Ions on the Urate Decomposition.

$\mathrm{Mg}$ ions were added as $\mathrm{MgCl}_{2}$.

$\mathrm{O}-\mathrm{O}$ Control (without addition),

O- O $10 \mathrm{~mm}$

- $100 \mathrm{~mm}$.

$1.0 \mathrm{~mm}$

$50 \mathrm{~mm}$ and

about an acceleration of the degradation, and of galactose, xylose, gluconate, glycerol and pyruvate were as half effective as glucose on the acceleration. The effect of glucose was maximum at the concentrations of $2 \sim 20 \mathrm{mM}$ as shown in Fig. 12. Some of di- and tricarboxylic acids of the TCA cycle had no effect on the decomposition, while some of lower fatty acids prevented the decrease in
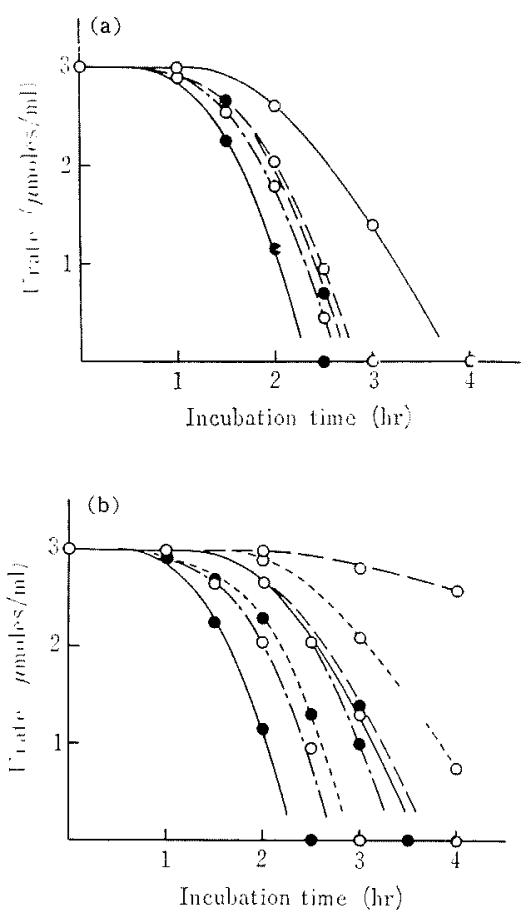

Fig. 11. Effect of Garbon Sources on the Urate Decomposition.

Carbon sources were added in the concentration of $10 \mathrm{mM}$.

(a) O-O Control (without carbon source), maltose, lactose, sucrose, mannitol, - glucose, fructose, mannose, -- galactose, $0--0$ xylose and O---O gluconate.

(b) O-O Control (without carbon source), glucose, $\mathrm{O}^{--} \bigcirc$ glycerol, ---- pyruvate, citrate, 2-oxo-glutarate, succinate, --- acetate, $\mathrm{O}-\mathrm{O}$ propionate and $\mathrm{O}-\mathrm{O}-\mathrm{O}$ butyrate.

urate in the mixture.

Chloramphenicol inhibited the uricase formation completely at a concentration as low as $0.5 \mathrm{mg} \%$ as seen from Fig. 13 .

Figure 14 shows a tipical experiment of the induced formation of uricase by the resting cells of this organism under the best conditions so far found. After a short lag period, a rapid increase in the uricase activity of the cells and a concomitant decrease in urate of the incubation mixture took place. The en- 


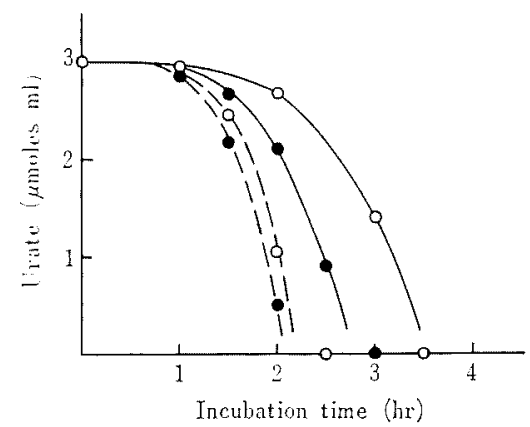

FIG. 12. Effect of Concentration of Glucose on the Urate Decomposition.

O-O Control (without glucose),

--- $2 \sim 20 \mathrm{~mm}$ and $\mathrm{O}^{--} \mathrm{O} 100 \mathrm{mM}$.

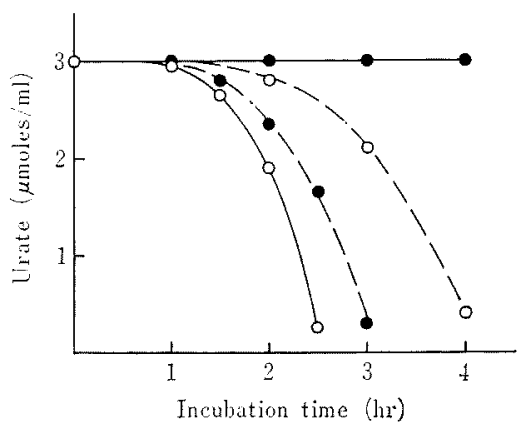

FIG. 13. Effect of Chloramphenicol on the Urate Decomposition.

O-O Control (without chloramphenicol), $0.05 \mathrm{mg} \%$, $0-0.1 \mathrm{mg} \%$ and $0.5 \sim 5.0$ mg\%.

zyme activity reached to its maximum value when urate in the mixture disappeared and amounted to 3.0 units per $g$ of wet cells. No appreciable change was noted in the cell weight during the incubation. Changes in the amount of uricase and urate when the cells were incubated in the absence of glucose and in the presence of chloramphenicol are also presented in Fig. 14.

The decomposition of urate and the accumulation of allantoin in the incubation mixture are shown in Fig. 15. The amount of allantoin accumulated was just equivalent to that of urate decomposed, and no further de-

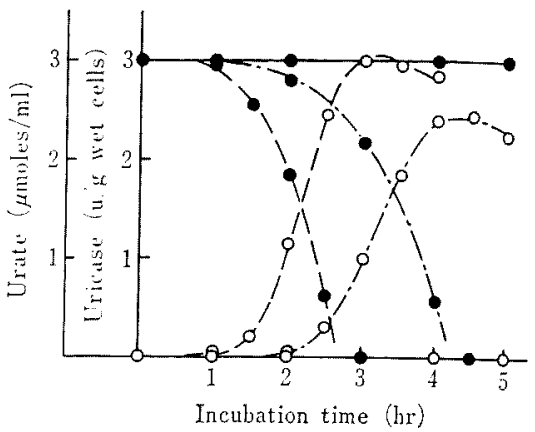

FIG. 14. Induced Formation of Uricase by the Resting Cells of Streptomyces sp.

Twenty milliliters of the incubation mixtures containing $0.5 \mathrm{~g}$ (wet weight) of washed cells previously grown in the peptone medium for $36 \mathrm{hr}$, $50 \mathrm{mM} \mathrm{K}$-phosphate buffer ( $\mathrm{pH} 7.0$ ), $10 \mathrm{mM} \mathrm{MgCl}_{2}$, $20 \mathrm{~mm}$ glucose and $3.0 \mathrm{~mm}$ urate were incubated at $30^{\circ} \mathrm{C}$ with shaking. In the case of incubation without glucose, glucose was omitted and of which with chloramphenicol, $1.0 \mathrm{mg} \%$ chloramphenicol was added.

Uricase: $\mathrm{O}^{--} \mathrm{O}$ with glucose, $\mathrm{O}--\mathrm{O}$ without glucose and $O-O$ with glucose and chloramphenicol. Urate: --- with glucose, without glucose and - with glucose and chloramphenicol.

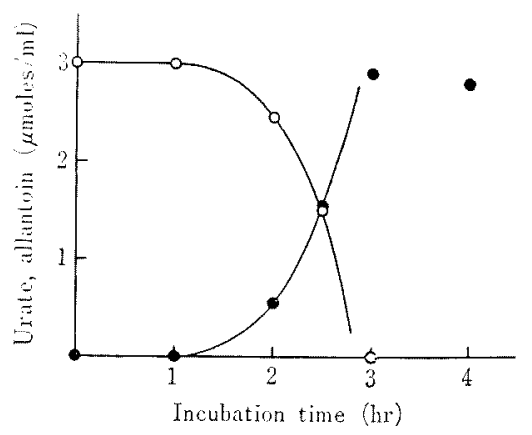

FIG. 15. Decomposition of Urate and Accumulation of Allantoin in the Incubation Mixture.

- $O$ Urate and - allantoin.

gradation was observed in allanioin even after a prolonged incubation.

\section{DISCUSSION}

A strain of Streptomyces sp. forms uricase 
inducibly. The formation of uricase, however, appeared to be repressed in the cells which were growing in the peptone medium. The presence of hypoxanthine or xanthine was required together with urate in the medium for the complete induction of uricase by the growing cells of this organism. ${ }^{6}$ In fact, as shown in Fig. 1, the activity of the enzyme was extremely low in the cells grown in the peptone medium regardless of the presence or absence of urate. This seems to be not due to the presence of inhibitors in the cells nor, as discussed later, to the existence of the enzyme as a pro- or masked-enzyme, but due to the substantial absence of the enzyme in the cells.

The cells grown in the peptone medium, however, were found to evoke the uricase formation, when the cells were incubated in $\mathrm{K}$-phosphate buffer with urate. Uricase activity in the cells increased rapidly and urate in the incubation mixture decreased concomitantly. Since the rate of urate uptake by the cells are proportional to uricase activity of the cells," the disappearance of urate from the incubation mixture was accelerated as the enzyme activity in the cells increased and then followed parabolic curves. The uricase formation of the incubated cells was found to be maximum by the cells previously grown in the peptone medium for $36 \mathrm{hr}$ as shown in Figs. 2 and 3. The presence or absence of urate and other purines in the medium for the preliminaly growth did not influence the uricase formation by the cells incubated in the phosphate buffer. The cells grown in the medium for $36 \mathrm{hr}$ under the present conditions were in the middle logarithmic phase of growth as seen in Fig. 1, and then may possess the highest physiological activities.

In addition to $\mathrm{Mg}$ ions which is known to be essential for the protein synthesis, $\mathrm{K}$ ions were also found to be required for the induced formation of uricase under the conditions

7) Y. Watanabe and J. Fukumoto, in preparation. studied (Figs. 7 and 9). Since $\mathrm{K}$ ions have been shown to be not requisite to the urate uptake by the cells, ") the effect should be on the enzyme formation. A preliminary investigation has suggested that the effect of $\mathrm{K}$ ions on the glucose metabolism might reflect on the uricase formation.

The formations of many of inducible enzymes are known to undergo the catabolite repression and be repressed in the presence of glucose. The induced formation of uricase, however, by this microorganism under the present conditions was found to be hastened in the presence of glucose (Fig. 11). The same effect was also brought about by fructose and mannose, which may be converted into glucose equivalent within the cells. Some of other sugars and other carbon sources such as galactose, xylose, gluconate, glycerol and pyruvate were also known to accelerate the uricase formation, although their effects were as about one half as of glucose. The difference in the effect of these carbon sources could be thought to stem from the difference in the metabolic rates of these substances.

The process has so far been not known through which the acceleration was produced in the presence of these carbon sources. Since the urate uptake by the cells has been found to be not affected by these sugars, ${ }^{7}$ they might influence the enzyme formation as energy sources. It may be seen from Fig. 14, however, that the induced formation of uricase did not necessarily require the supplement of these carbon sources to the incubation mixture. The amount of uricase produced by the cells incubated in the absence of glucose was almost equivalent to that produced in the presence of glucose. Only the difference between the uricase formation by these cells seemed to be the duration of the lag phase of the enzyme formation. It may be conceivable, therefore, that the effect of glucose would be to shorten the lag phase observed in the early period of the induction by furnishing energy necessary for the enzyme formation until the cellular 
energy reserves become available.

The cells grown in the peptone medium for $36 \mathrm{hr}$ contained almost no uricase and no appreciable increase in the enzyme occurred when the cells were allowed to continue the growth in the same medium for several hours even in the presence of urate. In contrast to the growing cells, the resting cells which were incubated with urate in the phosphate buffer could produce a remarkable amount of uricase in a short term. The enzyme formation thus evoked would be a de novo synthesis of the enzyme protein, since the formation was inhibited completely by chloramphenicol at a reasonably low concentration (Figs. 13 and 14). The urate uptake and the uricase activity of the cells have been shown to be not inhibited by chloramphenicol. ${ }^{7}$ Therefore, the uricase formation which would have been repressed in the growing cells might be derepressed in the resting cells incubated in the $K$-phosphate buffer. The amount of uricase thus formed by the resting cells exceeded 3.0 units per $g$ of wet cells, and was greater than that, 2.0 units per $g$ of wet cells, produced by the cultured cells, ${ }^{4,6)}$ although the quantitative difference would not be fundamental.

The results shown in Fig. 15 indicated that just an equimolar amount of allantoin to that of urate decomposed by the cells was accumulated in the incubation mixture, and suggested that this microorganism does not possess allantoinase even after being induced with allantoin and that the end product of purine catabolism may be allantoin in this organism. 